\title{
Differences In Problems Of Parents With Mentally Retarded Children
}

\author{
Dr, K .Radha Rani, \\ Course Director, DWMA, Kadapa and K.N.V.V.S.S.S.Chakravarthy, Lecturer SV.Arts college, \\ Tirupati
}

\begin{abstract}
The birth of the child either Normal or Retarded is known to produce pressure since it includes adjustments and extra responsibilities for various members of the family. However, birth of mentally retarded child produces greater pressure on the family because of extra demands of child care, greater financial burden. Hence an attempt was made to study the differences in problems of mothers and fathers having a mentally retarded child in a family. Families with mentally retarded children from RASS and MORE CBR projects in chittoor district of Andhra Pradesh numbering 200 families with boys and girls of age 6-15 yrs having mild moderate and severs levels of retardation was selected. Out of 200 families only 40 father and 200 mothers came forward voluntarily for the study. A designed parents problem inventory consist of nine problem areas (Family problems, Psychological, physical, social, professional advice, child rearing and management, psychosomatic, Financial and school adjustment and management).was used for the study. Results revealed the different most prevalent problems of mothers and father. Mothers expressed in laws find faults for birth of mentally retarded child, worry about future and marriage, find difficult to do thing independently, feel fatigue to look child's needs and house hold work, and suffered with giddiness and blood pressure while fathers reported, financial, physical, social, school and vocational problems.
\end{abstract}

Key words: mental retardation, problem inventory, parents problems with mentally retarded child

\section{INTRODUCTION:}

God created man and the man created several things including gods of his choice". This is possible for him with structural and functional specialties of his neurons in the brain centers, on the evolutionary front, the cranium size and attitudes to create and establish a feeling of universal oneness of human society. At such an unimaginable rate of changes in human genomes much concerned with the neurons of the brain and its network several sense, mis-sense and non- sense mutations are unavoidable giving rise to changes of all dimensions producing rulers on the top to an idiot on the lower rung of the ladder of human development. Thanks to the human genome it is producing 2 to $3 \%$ of the mentally retarded as against a good percent of normal humans. This low percent is not only due to genetic errors but also due to so many infectious diseases that the human embryo faces from the day of fertilization or due to epigenetic factors on the chromosomes of the male and female gametes.In India, it is reported to be around $2 \%$ for mild mental retardation and $0.5 \%$ for severe mental retardation (defined as IQ less than 50) (Srinath \& Girimaji, 1999).In National Sample Survey of 2004, 94 people per 100, 000 were found to be mentally retarded (National Sample Survey Organization, 2004). A series of factors are identifies that can cause mental retardation but even though in at least 30 to 50 percent of cases, physicians are unable to determine etiology despite thorough evaluation (Armatas, 2009).

Parents of mentally retarded children are known to experience many kinds' unusual impacts from the competitive society from time to manage and adjust to the best of their abilities. The impact includes, sad feeling of parents, depressed at various stages of child's life with experiences of many other emotional reactions. Their social life is often affected without much recreation and leisure for many positive opportunities and activities to score for their credit. The presence of a child with mental retardation in the family also calls for lot of adjustment on part of the parents and the other family members based on the severity of the problem. While raising a child with chronic condition, parents experience psychological stress and disappointment when their child does not meet their hopes and expectations (Barnett, Clements, Kaplan-Estrin, Fialka, 2003). Researchers has also indicated that greater the number of unmet needs, greater the number of emotional and physical problems reported by parents.(Dunst\&Leet 1987,Vence and Cooper 1986), (Kasuya, Polgar-Bailey, Takeuchi, 2000) reveled that" a multidimensional response to physical, psychological, emotional, social and financial stressors usually associated with the experience of caring" Objective burden includes measurable effects such as economic burden, caregivers' loss of work, social and leisure activities, household disruptions such as child care, restrictions on relationships within and outside the family etc. Subjective burden is mainly the psychological sufferings of the caregivers themselves and is experienced by them such as depression, hatred, 
uncertainty, guilt, shame, embarrassment etc (Ravindranadan\& Raju, 2007). Caring for those who are MRis often itself stressful as care-giving affects several aspects of caregiver's lifenegatively including poor physical and emotional state (Pinquart \& Sörensen, 2003; Vitaliano, Zhang, \& Scalan, 2003). Caregivers experience depression, burden, less social support, and less coping resources than non-caregivers (Vitaliano et al.,2002). Further Peshawaria and venketasan and menon (1988) analysed the consumer demand of services and reported that the needs for training in communication, management of behavioral problems and training in self help area were the most important for parents for which they out services. Hence the present study was an attempt to study problems of mothers and fathers having a child with mental retardation.

\subsection{Sample :}

\section{METHOD}

Families with mentally retarded children from RASS and MORE CBR projects in chittoor district of Andhra Pradesh numbering 200 families with boys and girls of age 6-15 yrs having mild moderate and severs levels of retardation was randomly selected.

\section{2 .Tools used :}

A parents problem inventory was designed for this study to assess the problems of mother and fathers with mentally retarded children. The parent problems inventory consist of 60 items distributed under nine problem areas (Family problems, Psychological, physical, social, professional advice, child rearing and management, psychosomatic, Financial and school adjustment and management). In each area 3-15 items and pretest was conducted for applicability. It is inferred that higher the score the greater the problem of parents with mentally retarded children and the test- retest reliability for each of the problem $\mathrm{s}$ is in range of $0.66-0.81$

\subsection{Procedure :}

A sample of 200 families with mentally retarded children form actively working organization like RASS and MORE CBR projects which was benefiting the society in chittoor district, are selected . Out of 200 families of mentally retarded children, only 40 father came forward voluntarily (after repeated counseling for them to participate) to share and express the problems with mentally retarded children. And all 200 mother came forward without hesitation. An interview method was adopted with an objective to assess the intensity of their problems that are faced by both father and mother with a mentally retarded child in a family.

\section{Results and Discussion:}

Table :3.1Socio demographic data of the study

\begin{tabular}{|l|l|l|l|l|}
\hline Variable & Item & Group & Number & Percentage \\
\hline \multirow{5}{*}{ Age } & Fathers & $30-40$ yrs & 16 & 40 \\
& & $41-50 \mathrm{yrs}$ & 10 & 25 \\
& & $51-60 \mathrm{yrs}$ & 14 & 35 \\
\cline { 2 - 5 } & Mothers & $20-30 \mathrm{yrs}$ & 59 & 29.5 \\
& & $31-40 \mathrm{yrs}$ & 69 & 34.5 \\
& & $41-50 \mathrm{yrs}$ & 72 & 36.5 \\
\hline \multirow{3}{*}{ Gender } & Male & & 40 & 20 \\
& Female & & 200 & 100 \\
\hline \multirow{3}{*}{ Education } & urban & & 107 & 53.5 \\
& rural & & 93 & 46.5 \\
& Fothers & Educated & 58 & 29 \\
& & Un educated & 142 & 71 \\
& & Educated & 22 & 55 \\
\hline income & Low & Un educated & 08 & 20 \\
& Middle & & 89 & 43 \\
& high & & 93 & 46.5 \\
\hline Family type & nuclear & & 21 & 10.5 \\
& joint & & 81 & 59.5 \\
& & & 44.5 \\
\hline
\end{tabular}

The table 3.1 above itself is a self explanatory with regarding to the socio demographic of the 200fanilies with mentally retarded children the percentages are depicted in the table. 
Table: 3.3Different Problems of mother and fathers with mentally retarded children in percentages

\begin{tabular}{|c|c|c|c|c|c|c|}
\hline \multirow{2}{*}{$\begin{array}{l}\text { Sno } \\
1 \\
\end{array}$} & \multirow{2}{*}{$\begin{array}{l}\text { Problem areas } \\
\text { Family problems (FP) }\end{array}$} & \multicolumn{2}{|c|}{$\begin{array}{l}\text { Mother } \\
\text { Number } \\
200 \%\end{array}$} & \multirow[t]{2}{*}{$\begin{array}{l}\text { Problem } \\
\text { areas }\end{array}$} & \multicolumn{2}{|c|}{$\begin{array}{l}\text { Father } \\
\text { Number } \\
40 \quad \%\end{array}$} \\
\hline & & & & & & \\
\hline & $\begin{array}{l}\text { FP3 } \\
\text { In-laws find faults with } \\
\text { me for birth of mentally } \\
\text { retarded child. }\end{array}$ & 151 & 75.5 & & & \\
\hline & $\begin{array}{l}\text { FP2 } \\
\text { Quarrels with each } \\
\text { other for child's extra } \\
\text { responsibility. }\end{array}$ & 149 & 74.5 & FP2 & 27 & 67.5 \\
\hline & $\begin{array}{l}\text { FP1 } \\
\text { Blame each other about } \\
\text { Childs condition. }\end{array}$ & 143 & 73 & FP1 & 25 & 65 \\
\hline \multirow[t]{3}{*}{2} & $\begin{array}{l}\text { Psychological } \\
\text { problem (PSY) }\end{array}$ & & & & & \\
\hline & $\begin{array}{l}\text { PSY1 } \\
\text { Shock about the child's } \\
\text { condition. }\end{array}$ & 114 & 57 & PSY1 & 22 & 55 \\
\hline & $\begin{array}{l}\text { PSY2 } \\
\text { Worry about future and } \\
\text { his/her marriage. }\end{array}$ & 101 & 50.5 & & & \\
\hline \multirow[t]{3}{*}{3} & $\begin{array}{l}\text { Physical problem } \\
\text { (PHY) }\end{array}$ & & & & & \\
\hline & $\begin{array}{l}\text { PHY1 } \\
\text { Never look after } \\
\text { himself independently. }\end{array}$ & 127 & 63.5 & $\begin{array}{l}\text { PHY8 } \\
\text { Have to carry } \\
\text { him where } \\
\text { ever I go. }\end{array}$ & 28 & 70 \\
\hline & $\begin{array}{l}\text { PHY2 } \\
\text { Feel fatigue to look } \\
\text { his/her needs and house } \\
\text { hold work. }\end{array}$ & & & $\begin{array}{l}\text { PHY1 } \\
\text { never look } \\
\text { after himself } \\
\text { independently. }\end{array}$ & 21 & 52.5 \\
\hline \multirow[t]{6}{*}{4} & Social problem (SOC) & & & & & \\
\hline & $\begin{array}{l}\text { SOC2 } \\
\text { Felt guilty to take the } \\
\text { retarded child out. }\end{array}$ & 151 & 75.5 & SOC2 & 31 & 77.5 \\
\hline & $\begin{array}{l}\text { SOC1 } \\
\text { Feel shameful if } \\
\text { someone points about } \\
\text { child's condition or } \\
\text { behavior. }\end{array}$ & 109 & 54.4 & SOC1 & 28 & 70 \\
\hline & & & & $\begin{array}{l}\text { SOC8I } \\
\text { it hurts me if } \\
\text { some one } \\
\text { indulges about } \\
\text { Childs } \\
\text { disability. }\end{array}$ & 28 & 70 \\
\hline & & & & $\begin{array}{l}\text { SOC3 } \\
\text { Habit of } \\
\text { frequent } \\
\text { quarreling } \\
\text { with other } \\
\text { children. } \\
\end{array}$ & 25 & 62.5 \\
\hline & & & & $\begin{array}{l}\text { SOC5 } \\
\text { Avoided to } \\
\text { mingle with }\end{array}$ & 25 & 62.5 \\
\hline
\end{tabular}




\begin{tabular}{|c|c|c|c|c|c|c|}
\hline & & & & $\begin{array}{l}\text { friends } \\
\text { relatives. }\end{array}$ & & \\
\hline & & & & $\begin{array}{l}\text { SOC6 } \\
\text { Neighbor's ill } \\
\text { treats the } \\
\text { child. }\end{array}$ & 25 & 62.5 \\
\hline \multirow[t]{6}{*}{5} & $\begin{array}{l}\text { School and vocational } \\
\text { problems (SAVP) }\end{array}$ & & & & & \\
\hline & $\begin{array}{l}\text { SAVP1 } \\
\text { Not aware of services } \\
\text { that are available for } \\
\text { him. }\end{array}$ & 126 & 63 & SAVP1 & 31 & 77.5 \\
\hline & & & & $\begin{array}{l}\text { SAVP3 } \\
\text { solutions to } \\
\text { the problems } \\
\text { related to } \\
\text { retardation }\end{array}$ & 29 & 72.5 \\
\hline & & & & $\begin{array}{l}\text { SAVP5 } \\
\text { how to train } \\
\text { the retarded } \\
\text { child }\end{array}$ & 28 & 70 \\
\hline & & & & $\begin{array}{l}\text { SAVP2 } \\
\text { No time to } \\
\text { attend the } \\
\text { training } \\
\text { programms } \\
\text { meant for } \\
\text { retarded child. }\end{array}$ & 28 & 70 \\
\hline & & & & $\begin{array}{l}\text { SAVP4 } \\
\text { Lack of } \\
\text { proper } \\
\text { training to } \\
\text { train the } \\
\text { retarded child. }\end{array}$ & 25 & 62.5 \\
\hline \multirow[t]{5}{*}{6} & $\begin{array}{l}\text { Financial } \\
\text { problems }(\mathbf{F N})\end{array}$ & & & & & \\
\hline & $\begin{array}{l}\text { FIN1 } \\
\text { expenditure on } \\
\text { medicines and material } \\
\text { for retarded child } \\
\text { development limits the } \\
\text { family well being }\end{array}$ & 108 & 68 & $\begin{array}{l}\text { FIN2 } \\
\text { No financial } \\
\text { help are } \\
\text { support from } \\
\text { in laws }\end{array}$ & 23 & 57.5 \\
\hline & & & & FIN1 & 22 & 55 \\
\hline & & & & $\begin{array}{l}\text { FIN4 } \\
\text { went for debts } \\
\text { for well being } \\
\text { and } \\
\text { improvement } \\
\text { in childs } \\
\text { condition }\end{array}$ & 22 & 55 \\
\hline & & & & $\begin{array}{l}\text { FIN5 } \\
\text { not aware of } \\
\text { financial } \\
\text { support } \\
\text { systems and } \\
\text { other sources } \\
\text { for retarded } \\
\text { children. }\end{array}$ & 22 & 55 \\
\hline 7 & Professional advise & & & & & \\
\hline
\end{tabular}




\begin{tabular}{|c|c|c|c|c|c|c|}
\hline & problems (PAP) & & & & & \\
\hline & $\begin{array}{l}\text { PAP1 } \\
\text { wrong advices and } \\
\text { suggestions from others }\end{array}$ & 157 & 78.5 & PAP2 & 29 & 72.5 \\
\hline & $\begin{array}{l}\text { PAP4 } \\
\text { un aware of guidance } \\
\text { and services exclusive } \\
\text { meant for retarded } \\
\text { child's }\end{array}$ & 129 & 69.5 & PAP1 & 25 & 62.5 \\
\hline & $\begin{array}{l}\text { PAP2 } \\
\text { lack of proper } \\
\text { information about } \\
\text { child's condition }\end{array}$ & 124 & 67 & PAP4 & 24 & 60 \\
\hline 8 & $\begin{array}{l}\text { Child rearing and } \\
\text { management } \\
\text { problems (CRMP) }\end{array}$ & & & & & \\
\hline & $\begin{array}{l}\text { CRMP1 } \\
\text { caring and nurturing } \\
\text { him strains me a lot. }\end{array}$ & 120 & 60 & CRM P1 & 21 & 52.5 \\
\hline & $\begin{array}{l}\text { CRM6 } \\
\text { find difficult to do } \\
\text { thing independently. }\end{array}$ & 106 & 53 & & & \\
\hline 9 & $\begin{array}{l}\text { Psychosomatic } \\
\text { problems (PSP) }\end{array}$ & & & & & \\
\hline & $\begin{array}{l}\text { PSP3 } \\
\text { loss of appetite due to } \\
\text { mental worry about the } \\
\text { Childs retardation and } \\
\text { his future }\end{array}$ & 133 & 66.5 & PSP1 & 26 & 65 \\
\hline & $\begin{array}{l}\text { PSP1 } \\
\text { head ach and burden } \\
\text { about the childs } \\
\text { retardation }\end{array}$ & 122 & 61 & PSP3 & 23 & 57.5 \\
\hline & $\begin{array}{l}\text { PSP2 } \\
\text { suffered with giddiness } \\
\text { and blood pressure }\end{array}$ & 112 & 56 & & & \\
\hline
\end{tabular}

The above present table- 3.3 represents the most prevalent problems expressed by mothers and fathers having a child with mental retardation in a family. In the table 3.3 percentages were computed and presented for each item in nine selected problem areas. The percentages obtained for each item under each of the nine selected problem areas ranges from $80 \%$ to $12.5 \%$ in descending order. A cut off point $50 \%$ was taken into account to represent the prevalent problem for both mothers and fathers, the percentages below $50 \%$ were considered as a problem but not as the most prevalent problem. Similarly, the values above 50\% were treated as most prevalent problemFrom the fore going data on items, it was clear that majority of the mother expressed family problems like blaming each other about the child's retardation, quarrels with spouse with extra responsibilities of the child, caring the retarded child limits the welfare of the other siblings and blaming by in laws for the birth of the retarded child. The present results were corroborated with Piper,(1976) who noted that the in laws resentment on daughter -in law for not producing a normal child was spectacular. Further regarding resentment of in-laws, it was brought out from the studies of Turnbull and Turnbull(1990); Ethyl et,al.,(1985).where as fathers also expressed such resentment under family problem like frequent quarreling with spouse for extra responsibility to retarded child. Blaming of each other for Childs condition and caring of the retarded child limits the welfare of the other siblings. The present study results was no line with the studies of Reeta peshawaria (1992), where she revealed that parenting the child with mental retardation was not easy job further in an another study Orr et.al.,(1991) stated that parents having a child with mental retardation experienced a variety stressors and stress reactions related to the child's disability as the child older.

It was clear from the results, except the blaming by in-laws the rest of the items expressed by both the mother and father was same in family problems area, however, majority of mothers in present study was blamed by their in-laws for giving birth to such child. 
In psychological problem area most mothers expressed, shock about their child's future. Most of the mothers expressed that they underwent mentally dull state by knowing the child's condition and it was coupled with the unsolved mental agony about the future of the child. However, majority of fathers also expressed the same situation about the future of the child. McConachie,(1986) noted that the mothers might be more risk for psychiatric problems than were fathers. Emotional reactions of parents were cited by Olshansky,(1962); Blacher,(1984); Wickler (1986),Bristol,(1987) and they revealed that the mothers suffered more emotional disturbances as compared to the fathers. These finding were in agreement with most of the emotional feelings in mothers of the chittoor district area was evident from results. However, it is understood that though the mothers give a went out to their emotional stress and strain but fathers appear to apparently suppress such feelings and consoled their wives and pretend a sort of boldness in the looks of viewers and sympathizers with self determination.

Majority of the mothers expressed the physical problems like giving bath to grownup child, find risk some difficulty to change the nap during menstruation while fathers expressed that they have to take where ever they go out and the children never look after themselves independently regarding the road rules, accidents, money holding and maintaining.

Regarding social problems they felt guilty to take the retreaded children out and felt shame if someone pointed their child's behavior, and teasing by other children, and mentally retarded often grew sensitive and quarrelsome with other children. Such problems was more expressed by fathers where as mothers expressed guilty feeling to take them out for outing and felt shameful if someone pointed about the Childs condition. And avoid looks to mingle with friends and relatives, and evade frequently the neighborhood problems. The present study results are on par with the study of Ravindranadan\& Raju, (2007) reveled Objective burden includes measurable effects such as economic burden, parents' loss of work, social and leisure activities, household disruptions such as child care, restrictions on relationships within and outside the family etc. Subjective burden is mainly the psychological sufferings of the caregivers themselves and is experienced by them such as depression, hatred, uncertainty, guilt, shame, embarrassment etc, Further, parents may develop low self esteem as a result of having a child with mental retardation. Cummings , Bayley, \& Rei,(1966); Rousso,(1984);Turn Bull \& Turn Bull, (1990)

Mothers expressed that they did not have the school and vocational problems need service facilities availability and they did not know how to train their retarded children, while fathers expressed how to know solutions to the problems for the items like whether they know how to train the mentally retarded child, whether they find time to train the Mentally retarded child, whether find time to attend training programs meant for them in special schools. Thus there was much difference for certain items between mothers and fathers in helping their mentally retarded child.

Mothers expressed with the items under financial problems that their, family life was affected due to increased responsibilities and financial stress, while fathers expressed that they did not get financial help from parents in-laws and their family life got affected. In addition increased responsibilities and financial stress due child, they went for debts for the wellbeing of the child and they were not aware of financial support from other sources. Financial stress and implications was studied on parents of mentally retarded by Turnbull,et al.,(1990)in his studies on family systems. Venkatesan and Das,(1994),on attitudes of parents, Minnes (1988) on the status of resources and socioeconomic conditions that created acute financial burdens on the parents with mentally retarded children. More are less an identical situation. Regarding the financial burden on parents of different socio economic groups with mentally retarded children also was evident from the present study. From the present studies it was learnt that the resentment of in-laws was very the unavoidable fall of mental retardation in 2-3\% of families without notice as a natural force which was far beyond the level of intellectual and scientific faculties either to control or to avoid it like the predisposed sin.

Mothers expressed the items under professional advice problem that they received wrong suggestions from others about their mentally retarded child, and quite un- aware of training and services centers for the retarded children, and could not procure proper information about child condition, while fathers expressed items with which they lacked a proper information about the mentally retarded child's condition, and also unaware of training and service centers meant for the retarded children and they also received wrong suggestions from others about improvement of mentally retarded child retardation. Peshawaria \& Menon 1991 also reported that main needs of parents because of having a child with mental handicap includes communication of diagnosis, parental and family adjustments, information on government benefits, future of the child, accessibility to formal and informal support and parent training programmes, In the present study both the mother are facing different problems having mentally retarded children. Hence mother and fathers in the present study requires early diagnosis of the condition, family adjustments, government benefits, formal and informal support and training progarmmes for better future of the retarded child.

Irrespective of the level of mental retardation; it is for sure that parents have to cope with their special needs and therefore disability in children is not only problem for affected children, but in real sense they are 'family 
disease. This seems more germane in our country where family bears the main stress of caring for such persons unlike in the developed world. Experts explain that in India families assume the role of primary caregivers for numbers of reasons (i) the Indian tradition of interdependence and concern for near and dear ones in adversities and (ii) there is a paucity of trained mental health professionals required to cater to the vast majority of the population; hence, the clinicians depend on the family" (Avasthi, 2010)

\section{CONCLUSION}

The presents study high lights the differences in problems of mothers and fathers having mentally retarded child. It is clear from study that mothers and fathers life style got affected, influencing every aspect of their life including their family, psychological, physical, financial, social, child rearing and management, vocational, professional advice and psychosomatic problems. Hence, from foregoing study it is clear that both mother and fathers require professionals need to understand the individual need of the each parent in context to their specific environment and provide individual need based intervention which in turn strengthen the mother and father in order to constructively contribute in the habilitation programmers of their mentally retarded child.

\section{REFERSNCES}

[1] Armatas, V. (2009). Mental retardation: definitions, etiology, epidemiology and diagnosis. Journal of Sport and Health Research, 1 (2): 112-122.

[2] Barnett, D., Clements, M., Kaplan-Estrin, M. \& Fialka, J. (2003). Building New Dreams, supporting parents' adaptation to their child with special needs, infants and young children, 16 (3): 184-200.

[3] Blacher,J (1984). Sequential stages of adjustment to the birth of a child with handicaps. Fact or artifacts. Mental Retardation.22.55-68.

[4] Bristol,M (1987).The home Care of Children with Developmental disabilities. Empirical support for a model of successful family coping With stress. InSLandesman,P.M.Vietze\&M.J.Begab(Eds), Living Environmets and mental retardation. Washington DC:American Association of Mental Deficiency.

[5] Cummings,ST;Bayley,H.C \& Rei,H.E.(1966). Effects of Childs deficiency on the mothers of mentally retarded chronically ill and neurotic children. American journal of orthopsychiatry,46,246-255

[6] Dunst CJ\&Leet,H.E (1987).Measuring the adequacy of resources in households in young children. Child care, health and development

[7] Dunst CJ.,Vence and Cooper (1986),A Social system perspectives

[8] of adolescent pregnancy: Determinates of parents and parents-child behavior. Infant mental health journal

[9] Ethyl et,al.,(1985).Working with parents of exceptional children. St.Louis. Times Mirror

[10] Kasuya, R.T., Polgar-Bailey, P. \& Takeuchi, R. (2000). Caregiver burden and burnout. A guide for primary care physicians. Post graduate Medicine, 108: 119-123.

[11] .McConachie,(1986.Parents of young mentally handicapped children. A review of research issues, London: Croom Helm .

[12] Minnes, P.M (1988). Family resources and stress associated with having a mentally retarded child . American journal of mental retardation.93;184-192

[13] National Sample Survey Organisation. A report on disabled persons. New Delhi: Department of Statistics, Government of India; 2004. Available at: www.ncasindia.org

[14] Olshansky, S(1962). Chronic sorrow: A response to having a mentally defective child. Social case work43.191-194.

[15] Orr et.al.,(1991).coping with stress in families with mentally retardation: An evaluation of ABCX model. American journal of mental retardation 95,444-450.

[16] Peshawaria, R \& Menon ,D.K(1991) Needs of famalie with mentally retarded children.. Indian journal of disability and Rehabilatation.

[17] Peshawaria,R, Venketasan.S and Menon, D.K(1988). Consumer demand of service by Parents of Mentally handicapped Children. Indian journal of Disability and Rehadiliration. June-Dec, 112-120

[18] Pinquart, M. \& Sörensen, S. (2003). Differences between caregivers and noncaregivers in psychological health and physical health: A meta analysis. Psychology and Aging, 18: 250-267.

[19] Piper,(1976). Grandparents can help.exceptional parents,Vol.6,pp 7-1

[20] 19.Ravindranadan, V. \& Raju, S. (2007). Adjustment and attitude of parents of children with mental retardation. Journal of the Indian

[21] Academy of Applied Psychology, 33: 137-141.

[22] Reeta peshawaria (1992). Meeting counseling needs of parents of disabled children. samadhan. News letter.

[23] Rousso,H.(1984).Fostering healthy self esteem. The Exceptional Parent,12(1)21-25.

[24] Srinath \& Girimaji, (1999). Epidemiology of child and adolescent mental health 
[25] problems and mentalretardation. NIMHANS Journal, 17 (4): 355-366.

[26] Venkatesan,S., and Das, A.K (1994). Reported the burden of family members in receiving /implementing home based training Programmes for children with mental handicaps. Journal of psychological Researches, Vol.38, No1and2.,pp.39-45.

[27] Vitaliano, P.P., Scanlan, J.M., Zhang, J., Savage, M.V., Hirsch, I.B. \& Siegler, I.C. (2002). A path model of chronic stress, the metabolic syndrome, and coronary heart disease. Psychosomatic Medicine, 64: 418-435.

[28] Vitaliano, P.P., Zhang, J. \& Scalan, J. (2003). Is care giving hazardous to one's physical health? A metaanalysis. Psychological Bulletin, 129: 946-972.

[29] Turnbull andTurnbull,(1990).Families , Professionals and Exceptionality : A special partnership.Columbus .OH. Charless Merrill.

[30] Wickler.L (1986).Periodic stresses to families of children with Mental Retardation. American journal of Mental Deficiency, 90,703-706. 